\title{
Sex of Mussel Mytilus coruscus (Bivalvia: Mytilidae) : Sequential Hermaphroditism
}

\author{
Hyeon Jin Kim', So Ryung Shin ${ }^{1}$, Han Young Oh', Jae Won Kim² , and ${ }^{\dagger}$ Jung Sick Lee ${ }^{1}$ \\ 'Dept. of Aqualife Medicine, Chonnam National University, Yeosu 59626, Korea \\ ${ }^{2}$ Dept. of Aquaculture, Gangwon State University, Gangneung 24525, Korea
}

Received: January 13, 2021

Revised: January 22, 2021

Accepted: January 29, 2021

\section{${ }^{\dagger}$ Corresponding author} Jung Sick Lee

Dept. of Aqualife Medicine, Chonnam National University, Yeosu 59626, Korea

Tel: +82-61-659-7172

Fax: +82-61-659-7179

E-mail: ljs@jnu.ac.kr

Copyright $\odot 2021$ The Korean Society of Developmental Biology.

This is an Open Access article distributed under the terms of the Creative Commons Attribution Non-Commercial License (http://creativecommons.org/licenses/ by-nc/4.0/) which permits unrestricted non-commercial use, distribution, and reproduction in any medium, provided the original work is properly cited.

ORCID

Hyeon Jin Kim

https://orcid.org/0000-0001-9208-4616 So Ryung Shin

https://orcid.org/0000-0002-2888-1378

Han Young Oh

https://orcid.org/0000-0001-8522-3913

Jae won Kim

https://orcid.org/0000-0002-9035-6005

Jung Sick Lee

https://orcid.org/0000-0001-6292-328X

Conflict of interests

The authors declare no potential conflict of interest.

Acknowledgements

Not applicable.

Authors' contributions

Conceptualization: Kim JW, Lee JS.

Data curation: Kim HJ, Shin SR.

Formal analysis: Kim HJ, Oh HY.

Methodology: Kim JW, Lee JS.

Software: Kim HJ, Shin SR.

Validation: Lee JS, Kim JW.

Investigation: Kim HJ, Shin SR, Oh HY,

\begin{abstract}
Samples were collected from the subtidal region of Jumunjin on the eastern coast of Korea in July 2020. A total of 338 mussels of shell height (SH) 20.8-149.8 mm were used for sex ratio analysis. The sex ratio (F:M) in the same population of mussel Mytilus coruscus was approximately $1: 0.7$. The sex ratio according to the class of $\mathrm{SH}$ was different. The sex reversal pattern of $M$. coruscus appears to go from male $\rightarrow$ female $\rightarrow$ male $\rightarrow$ female, and as such is determined to be sequential hermaphrodites.
\end{abstract}

Keywords: Mytilus coruscus, Sequential hermaphroditism, Sex reversal

\section{INTRODUCTION}

In general, the determination of animal sex is based on their morphological sex. Sex of bivalves can be categorized as either gonochoristic or hermaphroditic, whereas hermaphrodites can be described as either simultaneous or sequential (Coe, 1943; Heller, 1993; Yusa, 2007). Sequential hermaphrodites undergo sex changes during their life cycle, and their morphological sex is expressed differently according to the life cycle stage. The identification of sequential hermaphroditism requires direct evidence of sex change (Coe, 1943; Lee et al., 2013, 2014). However, since obtaining direct evidence requires considerable time and effort, an indirect method is used to analyze the change in sex ratio according to age or size within the same population (Galtsoff, 1937; Guo et al., 1998; Eversole, 2001; Park et al., 2012). The purpose of this study was to analyze the sex ratio of the mussel Mytilus coruscus, which is known to be gonochoristic (Wi et al., 2003), to thus describe its sex changes and sex.

\section{MATERIALS AND METHODS}

Mussels were collected from the subtidal region of Jumunjin on the eastern coast of Korea in July 2020 (Fig. 1). A total of 338 mussels of shell height (SH) 20.8-149.8 mm were used for sex ratio analysis. Sex was confirmed by observing anatomical and microscopic tissue specimens (Fig. 2). The sex ratio was recorded by dividing into classes of SH $10.0 \mathrm{~mm}$ each. The sex ratio (F:M) was expressed as the ratio of males $(\mathrm{M})$ to females $(\mathrm{F})$ and the female proportion (\%) of the total, and statistical analysis was performed using the Chi-square $\left(\chi^{2}\right)$ test. 
Kim JW.

Writing-original draft: Kim HJ, Lee JS.

Writing-review \& editing: Kim HJ, Shin SR, Lee JS.

\section{Ethics approval}

This article does not require IRB/IACUC approval because there are no human and animal participants.

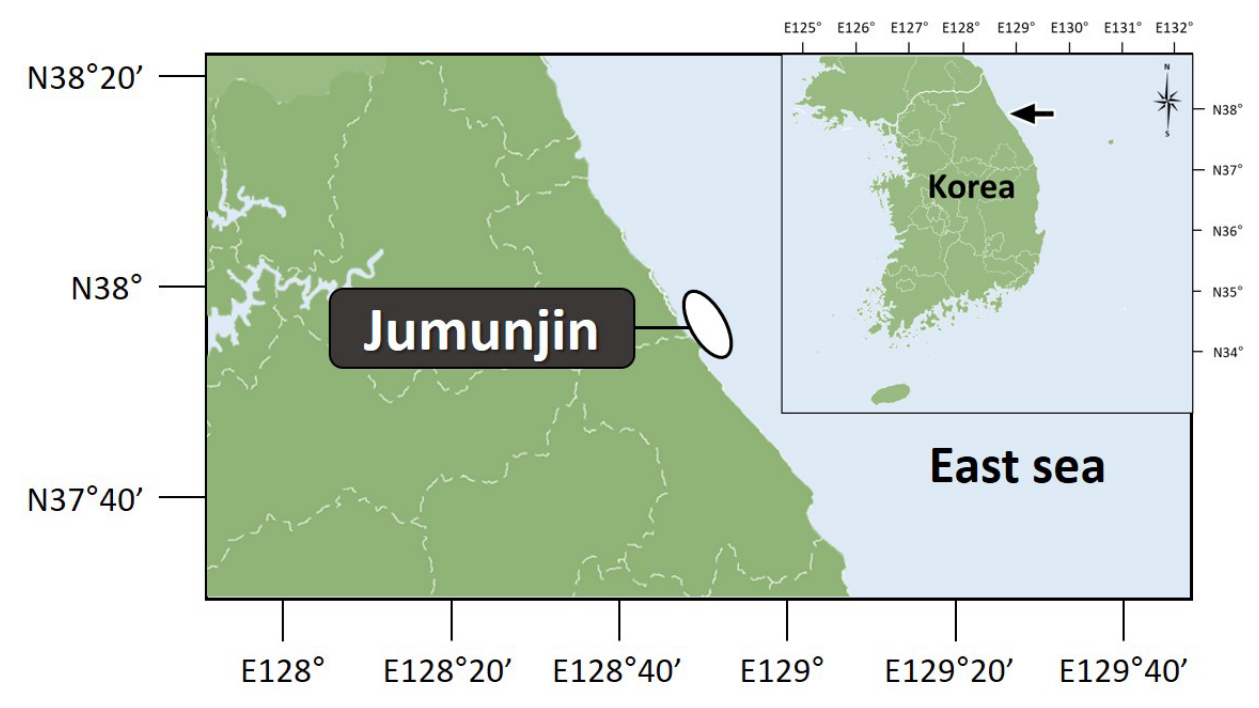

Fig. 1. Sampling area of Mytilus coruscus.
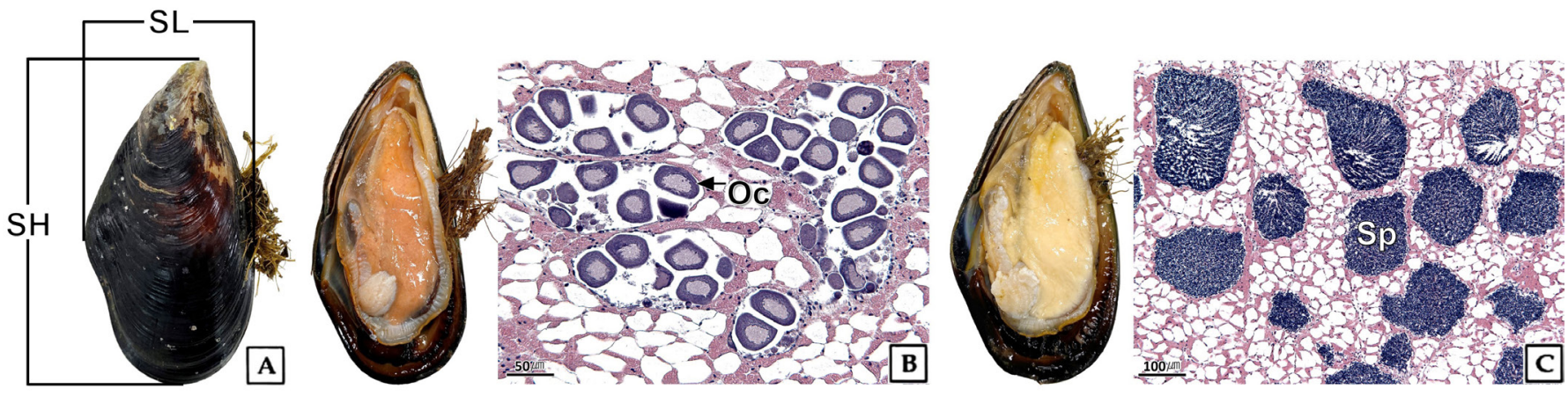

Fig. 2. Morphocharacteristics (A), anatomy and histology of gonad in Mytilus coruscus. (B) female, (C) male. Oc, oocyte; SH, shell height; SL, shell length; Sp, sperm.

\section{RESULTS AND DISCUSSION}

The overall sex ratio of mussels was approximately 1:0.7. However, the sex ratio according to the class of SH was different, where the male proportion was high in classes of SH 20.1-50.0 mm, but the female proportion was high in the SH 50.1-70.0 mm classes. The ratio of males was higher again in the SH 70.1-80.0 mm class, whereas the ratio of females was higher in the above $\mathrm{SH}$ $80.1 \mathrm{~mm}$ classes (Table 1). These results indicate that mussels are sequential hermaphrodites that periodically change $\operatorname{sex}($ ( $) \rightarrow$ 우 $\rightarrow$ 송 $\rightarrow$ 우).

Sex change normally occurs during the gonadal inactive stage in bivalves include Crassostrea virginica, C. gigas, Ruditapes philippinarum and Tegillarca granosa (Thompson et al., 1996; Park et al., 2012; Lee et al., 2013, 2014). However, sex change in Patinopecten yessoensis occurs during the gonadal active stages (Osanai, 1975). Genetic and environmental factors such as temperature affect the sex determination and change of sex ratio in bivalves (Yusa, 2007). It was confirmed in this study that the sex ratio and change according to shell size of $M$. coruscus. Therefore, more detailed research is needed on the season and factors involved in the sex changes of $M$. coruscus. 
Table 1. Sex ratio with shell height of mussel Mytilus coruscus

\begin{tabular}{|c|c|c|c|c|c|c|c|c|c|}
\hline \multirow{2}{*}{$\begin{array}{l}\text { Shell height } \\
(\mathrm{mm})\end{array}$} & \multicolumn{3}{|c|}{ Number } & \multirow{2}{*}{$\begin{array}{l}\text { Sex ratio } \\
(\mathrm{F}: \mathrm{M})\end{array}$} & \multirow{2}{*}{ Female (\%) } & \multirow{2}{*}{ Male (\%) } & \multirow{2}{*}{ Chi-square } & \multirow{2}{*}{ p-value } & \multirow{2}{*}{ Dominant sex } \\
\hline & Total & Female & Male & & & & & & \\
\hline $20.1-30.0$ & 35 & 14 & 21 & $1: 1.50$ & 40.00 & 60.00 & 1.40 & 0.310 & \multirow{2}{*}{$\delta$} \\
\hline $40.1-50.0$ & 41 & 19 & 22 & $1: 1.16$ & 46.34 & 53.66 & 0.22 & 0.759 & \\
\hline $50.1-60.0$ & 57 & 30 & 27 & $1: 0.90$ & 52.63 & 47.37 & 0.16 & 0.795 & ㅇ \\
\hline $80.1-90.0$ & 33 & 21 & 12 & $1: 0.57$ & 63.64 & 36.36 & 2.46 & 0.158 & \multirow{4}{*}{ 우 } \\
\hline $90.1-100.0$ & 36 & 24 & 12 & $1: 0.50$ & 66.67 & 33.33 & 4.00 & 0.061 & \\
\hline $100.1-110.0$ & 30 & 18 & 12 & $1: 0.67$ & 60.00 & 40.00 & 1.20 & 0.365 & \\
\hline $110.1-120.0$ & 32 & 28 & 4 & $1: 0.14$ & 87.50 & 12.50 & 18.00 & $<0.001$ & \\
\hline
\end{tabular}

\section{REFERENCES}

Coe WR (1943) Sexual differentiation in mollusks. I. Pelecypods. Q Rev Biol 18:154-164.

Eversole AG (2001) Reproduction in Mercenaria mercenaria. In: Kraeuter JN, Castagna M (eds), Biology of the Hard Clam. Elsevier, New York, NY, pp 221-260.

Galtsoff PS (1937) Observations and experiments on sex change in the adult American oyster, Ostrea virginica. Collect Net 12:187.

Guo X, Hedgecock D, Hershberger WK, Cooper K, Allen Jr SK (1998) Genetic determinants of protandric sex in the Pacific oyster, Crassostrea gigas Thunberg. Evolution 52:394-402.

Heller J (1993) Hermaphroditism in molluscs. Biol J Linn Soc 48:19-42.

Lee JS, Park JJ, Shin YK, Kim H, Jeon MA (2014) Sex change and sequential hermaphroditism in Tegillarca granosa (Bivalvia: Arcidae). Invertebr Reprod Dev 58:314-318.

Lee JS, Park JS, Shin YK, Lee YG, Park JJ (2013) Sequential hermaphroditism in Manila clam Ruditapes philippinarum (Bivalvia: Veneridae). Invertebr Reprod Dev 57:185-188.

Osanai K (1975) Seasonal gonad development and sex alteration in the scallop, Patinopecten yessoensis. Bull Mar Biol Stn Asamushi Tokyo Univ 15:81-88.

Park JJ, Kim H, Kang SW, An CM, Lee SH, Gye MC, Lee JS (2012) Sex ratio and sex reversal in two-year-old class of oyster, Crassostrea gigas (Bivalvia: Ostreidae). Dev Reprod 16:385-388.

Thompson RJ, Newell RIE, Kennedy VS, Mann R (1996) Reproductive process and early development. In: Kennedy VS, Newell RIE, Eble AF (eds), The Eastern Oyster: Crassostrea virginica. Maryland Sea Grant, College Park, MD, pp 335-370.

Wi CH, Chang YJ, Lee SJ, Hur YB, Lee JS (2003) Sexual maturation and gametogenic cycle of the hard shelled mussel, Mytilus coruscus (Bivalvia: Mytilidae). Aquaculture 16:245-251.

Yusa Y (2007) Causes of variation in sex ratio and modes of sex determination in the Mollusca: An overview. Am Malacol Bull 23:89-98. 
